\title{
PEMBANGUNAN KARAKTER SISWA SD \\ DITINJAU DARI LATAR BELAKANG KEBUDAYAAN DI LERENG GUNUNG SLAMET
}

\author{
Itsna Oktaviyanti ${ }^{1}$, Kiki Indah Pratiwi ${ }^{2}$ \\ ${ }^{1}$ Universitas Mataram, Mataram, Nusa Tenggara Barat \\ ${ }^{2}$ SD Negeri Tegalsari 13, Tegal, Jawa Tengah \\ *Corresponding Address: itsna@unram.ac.id
}

Naskah diterima: 1 November 2021| Disetujui: 8 November 2021 | Diterbitkan: 14 November 2021

\begin{abstract}
This research aimed to know the process of character building of primary school students and reviewed from the cultural background in Lereng Gunung Slamet. Research method used was qualitative with interpretative approach. Data were collected by using interview and documentation. Then data source was students, teachers, parent of SD Negeri 1 Serang and people while determination of informants used purposive sampling. Data analysis technique was begun by reducing data, presenting data and verification. Research result was that cultural background in lereng Gunung Slamet built students' characters of SD Negeri 1 Serang. These were because characters built by language elements were friendly and communicative, livelihood elements were discipline, hard work, environmental care, and responsible, religious element were tolerance, honest, loving peace and social care, and last was art and traditional elements where art built characters of creative, loving the homeland, friendly/communicative, and spirit of nationality, while tradition built characters of religious, loving homeland, tolerance spirit of nationality, loving piece, social care and environmental care.
\end{abstract}

Keywords: characters students, elementary school, culture, Mount Slamet

Abstrak: Penelitian ini bertujuan untuk mengetahui proses pembentukan karakter siswa sekolah dasar ditinjau dari latar belakang kultural di lereng Gunung Slamet. Metode penelitian yang digunakan adalah kualitatif dengan pendekatan interprentatif. Data dikumpulkan dengan menggunakan wawancara dan dokumentasi. Kemudian sumber data untuk penelitian ini yaitu siswa, guru, orang tua siswa SD Negeri 1 Serang, dan masyarakat sekitar, sedangkan penentuan informan menggunakan purposive sampling. Teknik menganalisis data dimulai dari mereduksi data, menyajikan data, dan verifikasi. Hasil dari penelitian menunjukkan bahwa latar belakang kultural di lereng Gunung Slamet membentuk karakter siswa SD Negeri 1 Serang. Hal tersebut tampak pada unsur bahasa yang membentuk karakter karakter bersahabat/komunikatif. Unsur mata pencaharian membentuk karakter disiplin, kerja keras, peduli lingkungan, dan tanggung jawab. Selain itu unsur religi membentuk karakter di antaranya toleransi, religius, jujur, cinta damai, dan peduli sosial. Unsur terakhir adalah kesenian dan tradisi di mana kesenian membentuk karakter kreatif, cinta tanah air, bersahabat/komunikatif dan semangat kebangsaan, sedangkan tradisi membentuk karakter religius, cinta tanah air, toleransi, semangat kebangsaan, cinta damai, peduli sosial, dan peduli lingkungan.

Kata kunci: karakter siswa, sekolah dasar, kultural, Gunung Slamet 


\section{PENDAHULUAN}

Kurikulum merupakan suatu acuan dalam melaksanakan pendidikan. Kurikulum mengatur segala hal, baik mata pelajaran yang diajarkan hingga pendekatan yang digunakan. Hal tersebut dilakukan untuk menyesuaikan perkembangan jaman, karakteristik peserta didik pada masa itu, dan kemampuan peserta didik dan pendidik. Oleh karena itu, kurikulum Indonesia mengalami perubahan sebanyak 10 kali. Setiap terjadinya perubahan dalam kurikulum, terdapat tujuan baru yang berbeda dengan kurikulum sebelumnya, hal itu disesuaikan dengan kebutuhan dan karaktertistik pendidikan pada masa itu, termasuk kurikulum yang sedang berjalan yaitu kurikulum 2013.

Kurikulum 2013 dikenal dengan sebutan kurikulum berbasis karakter. Alasan dari label tersebut adalah karena kurikulum 2013 mengutamakan pada ranah pembentukan karakter tanpa menghilangkan ilmu pengetahuan. Pembentukan karakter peserta didik pada jenjang sekolah dikenal dengan istilah Pendidikan Karakter. Pendidikan karakter merupakan program pendidikan yang bertujuan menghasilkan manusia yang bermoral dan berakhlak mulia dengan mengaplikasikan nilainilai kebijakan sebagai pribadi, warga negara dan masyarakat global. Sehingga pendidikan karakter pada kurikulum 2013 diharapkan mampu membentuk watak dan moral anak bangsa (Pranata, 2013).

Fokus Kurikulum 2013 berbeda dengan kurikulum-kurikulum sebelumnya yang lebih mengutamakan pengetahuan pada masing-masing mata pelajaran untuk dikuasai siswa. Karakter yang diharapkan dapat dikuasai atau melekat pada siswa ada 18 di antaranya yaitu toleransi, religius, jujur, kreatif, disiplin, demokratis, kerja keras, mandiri, cinta tanah air, rasa ingin tahu, semangat kebangsaan, menghargai prestasi, bersahabat/komunikatif, gemar membaca, cinta damai, peduli sosial, tanggung jawab, dan peduli lingkungan. Kedelapam belas karakter tersebut diharapkan dapat menempel pada diri siswa di seluruh Indonesia. Sehingga tujuan kurikulum 2013 dapat tercapai.

Seperti yang sudah dijelaskan sebelumnya, salah satu alasan perubahan kurikulum disesuaikan dengan karakteristik siswa pada masa itu. Kurikulum 2013 dirumuskan atas dasar pemikiran bahwa siswa yang sedang menempuh pendidikan dirasa kurang berkarakter. Kurang berkarakter dalam hal ini artinya siswa kurang memiliki moral yang bagus atau sikap yang seharusnya dimiliki oleh seseorang yang berpendidikan. Rahayu menjelaskan bahwa maraknya tindakan amoral yang bahkan dilakukan oleh siswa SD diantaranya mencontek, berkata kotor, tidak sopan kepada orang yang berusia lebih tua, tidak menghargai teman hingga karyawan di sekolah yang mengakibatkan munculnya persepsi kegagalan pendidikan dalam perannya membentuk moralitas bangsa (Rahayu, 2016). Pernyataan tersebut diperkuat oleh berita online sindonews yang berisi siswa SD melawan gurunya karena ditegur saat merokok. Artikel tersebut menjelaskan bahwa siswa berinisial RA berkata kasar dan menantang Munari, guru kelas yang sedang menasehati. Bahkan siswa tersebut 
memakinya dengan kata-kata kotor yang tidak layak dilontarkan oleh anak-anak seusianya saat RA dipanggil ke ruang kepala sekolah. Hal tersebut menjadi dasar pemerintah merumuskan kurikulum yang dapat membentuk dan mendukung pembentukan karakter anak Indonesia melalui pendidikan.

Pendidikan karakter selayaknya tidak hanya ditanamkan pada jenjang pendidikan formal di sekolah melainkan bisa melalui lembaga lain yaitu keluarga. Justru keluarga merupakan tempat pembentukan karakter yang utama. Keluarga merupakan lingkungan pertama dan paling intensif berhubungan dengan kehidupan anak. Dasar karakter terbentuk sedari anak mendapatkan contoh dari proses sosialisasi yang dilakukan, dan keluarga merupakan tempat pertama anak bersosialisasi dan mendapatkan pendidikan. Selain itu, waktu bersama keluarga lebih banyak dari waktu pendidikan di sekolah formal. Namun, tidak semua keluarga mampu dan terampil dalam proses pembentukan karakter anak, sehingga perlu ada lembaga lain yang dapat membantu, dalam hal ini yaitu lembaga sekolah yang menjadi tempat pendidikan kedua bagi anak terutama jenjang pendidikan dasar. Pendidikan dasar merupakan jenjang pendidikan formal pertama yang ditempuh oleh anak sehingga pembentukan karakter sangat bergantung pada jejang pendidikan ini. Selain itu, lembaga lain yang tidak kalah penting dalam membentuk karakter anak adalah masyarakat. Masyarakat memegang peranan yang sama pentingnya dengan keluarga dan sekolah, karena masyarakat merupakan wadah bersosialisasi yang cukup intens bagi anak pada dunia pertemanannya. Hal tersebut sejalan dengan pernyataan dari Kaimuddin, perlu adanya kerjasama dan komunikasi yang baik sebagai bentuk tanggung jawab dari sekolah, keluarga, dan masyarakat dalam membentuk siswa yang berkarakter (Kaimuddin, 2014).

Dalam membentuk karakter ada beberapa metode atau cara yang dilakukan baik oleh lembaga sekolah, keluarga, maupun masyarakat. Salah satunya dengan latar belakang kultural di daerah tersebut. Kultur atau budaya merupaka semua tingkah laku dan kepercayaan yang dipelajari oleh seseorang secara terus menerus dan teratur, kemudian budaya tersebut menjadi ciri khas dari suatu lingkungan masyarakat tertentu yang membedakan dengan lingkungan masyarakat lain. Oleh karena itu, semakin banyak lingkungan masayarakat maka semakin beragam budaya seperti halnya di negara Indonesia.

Dalam proses membudaya perlu adanya pelestarian agar budaya yang dimiliki dapat terus ada bahkan berkembang. Proses membudaya terjadi melalui beberapa lembaga baik sekolah, keluarga, maupun masyarakat. Adapun unsur kebudayaan yang bersifat universal menurut pendapat Kluckhohn diantaranya bahasa, organisasi sosial, sistem mata pencaharian hidup, sistem peralatan hidup dan teknologi, sistem religi yang berwujud ibadah maupun keyakinan yang dianut oleh masyarakat, sistem pengetahuan, dan kesenian atau tradisi yang melekat pada suatu kelompok masyarkat 
(Koentjaraningrat, 2015). Unsur-unsur budaya tersebut dapat membentuk perilaku manusia dari sejak kecil dan berkontribusi dalam pembentukan karakter. Setiap manusia memiliki budaya yang berbeda satu dan lainnya, hal tersebut berdasarkan latar belakang kultural masing-masin tidak terkecuai siswa sekolah dasar.

Latar belakang kultural dapat membentuk karakter siswa pada tingkat sekolah dasar dan hal tersebut tak terlepas dari dukungan sekolah, keluarga, dan masyarakat. Karakter yang terbentuk merepresentasikan seberapa besar nilai yang tergantung pada budaya yang melekat pada masyarakat di daerah tersebut. Kebudayaan masing-masing daerah berbeda, tergantung dari letak geografis, keadaan alam serta sejarah yang dialami oleh masyarakat daerah tersebut. Selan itu, budaya masingmasing daerah juga bisa dipengaruhi oleh pendatang di daerah tersebut, pendatang yang memiliki budaya kuat dan memilki power yang tinggi memungkinkan mempengaruhi kebudayaan yang ada di daerah yang didatangi. Masyarakat yang hidup di daerah perkotaan memiliki budaya yang berbeda dengan masyarakat di pedesaan, kemudian budaya pada masyarakat daerah pantai berbeda dengan budaya di daerah pegunungan. Artinya, setiap daerah memilki budaya lokal yang unik dan dapat berperan dalam pembentukan karakter manusia di dalamnya. Pembentukan karakter melalui budaya lokal dirasa tepat karena budaya lokal dapat memberikan pelajaran kepada siswa untuk senantiasa lekat dengan keadaan konkrit dalam kehidupan sehari-hari (Sudarmiani, 2013). Salah satu desa di lereng Gunung Slamet memiliki budaya yang melekat begitu kuat sehingga dapat mempengaruhi pembentukan karakter pada anak terutama pada siswa sekolah dasar. Artikel ini akan membahas bagaimana pembentukan karakter siswa sekolah dasar khususnya ditinjau dari latar belakang kultural di lereng Gunung Slamet.

\section{METODE PENELITIAN}

Penelitian ini merupakan penelitian kualitatif dengan pendekatan interpretatif untuk mengetahui pembentukan karakter siswa sekolah dasar ditinjau dari latar belakang kultural di lereng Gunung Slamet. Fokus penelitian ini ialah pada pembentukan karakter siswa di SD N 1 Serang yang terletak di lereng Gunung Slamet. Teori yang digunakan dalam penelitian ini adalah teori Teori Pierre Bourdieu.

Dalam teorinya, Bourdieu menjelaskan bahwa Habitus adalah suatu sistem disposisi yang berlangsung lama dan berubah-berubah (durable, transposible disposition) yang berfungsi sebagai basis generatif bagi praktik-praktik yang terstruktur dan terpadu secara objektif (Bourdieu dalam Harker dkk, 2009). Habitus bisa dikatakan sebagai ketidaksadaran-kultural, yakni pengaruh sejarah yang secara tak sadar dianggap alamiah (Harker dkk, 2009). Melalui konsep Habitus, maka dalam 
membentuk karakter siswa dapat melalui kebiasaan-kebiasaan yang berasal budaya yang telah ada dan melekat pada diri siswa.

Pada teori tersebut, karakter atau perilaku seseorang dibentuk melalui kebiasaan yang dilakukan dalam kehidupan sehari-hari. Kebiasaan tersebut dipelajari oleh siswa dari arena yang melingkupi siswa. Arena tersebut diantaranya sekolah, keluarga, dan masyarakat. Dengan demikian teori Bourdieu menjadi teori dasar dalam pelaksanaan penelitian ini.

Data penelitian dikumpulkan melalui metode wawancara mendalam serta metode dokumentasi. Kemudian sumber data penelitian yang dipilih yaitu siswa, guru, orang tua, dan masyarakat sekitar, sedangkan penentuan informan menggunakan purposive sampling sesuai dengan kebutuhan dalam penelitian. Kebutuhan dalam penelitian ini merupakan orang-orang yang merupakan subjek penelitian dan orang di sekitar subjek penelitian. Berdasarkan kebutuhan penelitian, sampel informan pada penelitian ini diantaranya guru, siswa, dan orang tua. Kemudian setelah turun ke lapangan, peneliti merasa perlu menggunakan snowball sampling karena dirasa perlu sampel tambahan agar hasil penelitian menjadi valid. Sampel tambahan di antaranya jumlah siswa, orang tua yang diwawancarai, pedagang yang berada di sekolah, serta pejabat desa setempat. Jumlah siswa yang menjadi subjek keseluruhan untuk penelitian ini adalah 18 siswa, yang terdiri dari 3 siswa pada masing-masing jenjang kelas. Informan guru sebanyak 3 orang, yaitu guru kelas I, guru kelas IV, dan guru kelas VI. Kemudian untuk orang tua siswa dari 18 siswa yang menjadi subjek dalam penelitian ini adalah 9 orang tua yang dijadikan informan.

Teknik pemeriksaan keabsahan data untuk penelitian ini adalah menggunakan teknik triangulasi. Triangulasi pada pada teknik pengumpulan data, diartikan sebagai teknik yang menggabungkan beberapa teknik pengumpulan data dan penggabungan beberapa sumber data (Sugiyono, 2018). Jadi dapat disimpulkan bahwa dengan triangulasi, maka secara tidak langsung peneliti telah mengumpulkan data sekaligus menguji kredibilitas data, melalui berbagai teknik pengumpulan data serta sumber data. Langkah selanjutnya adalah menganalisis data. Teknik menganalisis data dimulai dari mereduksi data, menyajikan data, dan menarik kesimpulan atau verifikasi yang merupakan teori analisis dari Miles and Huberman.

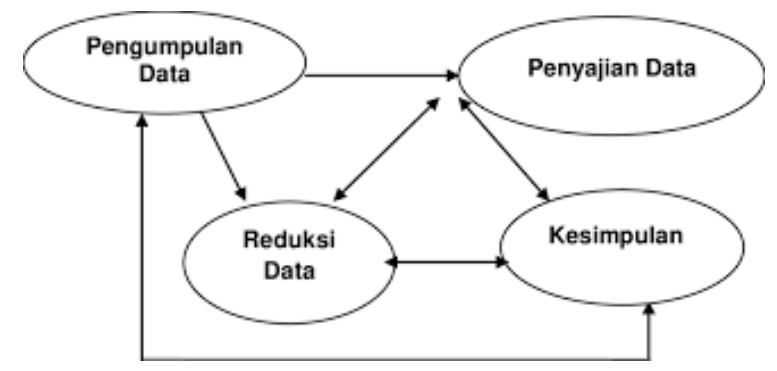

Gambar 1. Analisis Miles and Huberman 


\section{HASIL DAN PEMBAHASAN}

\section{Karakter Siswa di SD Negeri 1 Serang}

Sebelum adanya kurikulum 2013, penanaman karakter seolah menjadi tanggung jawa mata pelajaran Agama, namun pada kenyataannya masyarakat merasa pendidikan Agama belum mampu menyentuk aspek tersebut dengan baik. Oleh karena itu, pemerintah termotivasi untuk merumuskan inovasi baru dalam pengembangan pendidikan (Putry, 2018). Seperti yang telah dijelaskan sebelumnya, pendidikan karakter yang dimasukan dalam kurikulum 2013 ada 18 karakter. Di SD Negeri 1 Serang yang juga menggunakan kurikulum 2013, ke 18 karakter tersebut diinternalisasi melalui proses pembelajaran yang terarah. Dengan ditanamkannya pendidikan karakter, siswa di SD Negeri 1 Serang tumbuh menjadi siswa yang berkarakter seperti tujuan pendidikan yang ingin dicapai.

Sesuai hasil wawancara yang dilakukan sebagian siswa sudah memiliki 18 karakter yang dibutuhkan yaitu religius, toleransi, jujur, disiplin, kreatif, kerja keras, demokratis, mandiri, rasa ingin tahu, cinta tanah air, semangat kebangsaan, menghargai prestasi, cinta damai, bersahabat/komunikatif, gemar membaca, peduli sosial, tanggung jawab, dan peduli lingkungan. Meskipun demikian tidak semua siswa memiliki semua karakter tersebut. Ada beberapa siswa yang hanya memiliki 10 karakter dan bahkan beberapa hanya memiliki 3 karakter saja. Jumlah karakter yang dimiliki siswa berbeda, tergantung dari individu masing-masing. Selain hasil wawancara, hasil observasi dan dokumentasi mendukung infomasi yang disampaikan oleh informan. Salah satu karakter yang sangat sedikit dimiliki oleh siswa adalah jujur, kreatif, mandiri, gemar membaca dan peduli lingkungan. Sedangkan karakter yang banyak dimiliki oleh siswa adalah religius, toleransi, demokratis, bersahabat, dan peduli sosial. Berikut data karakter siswa di SD Negeri 1 Serang.

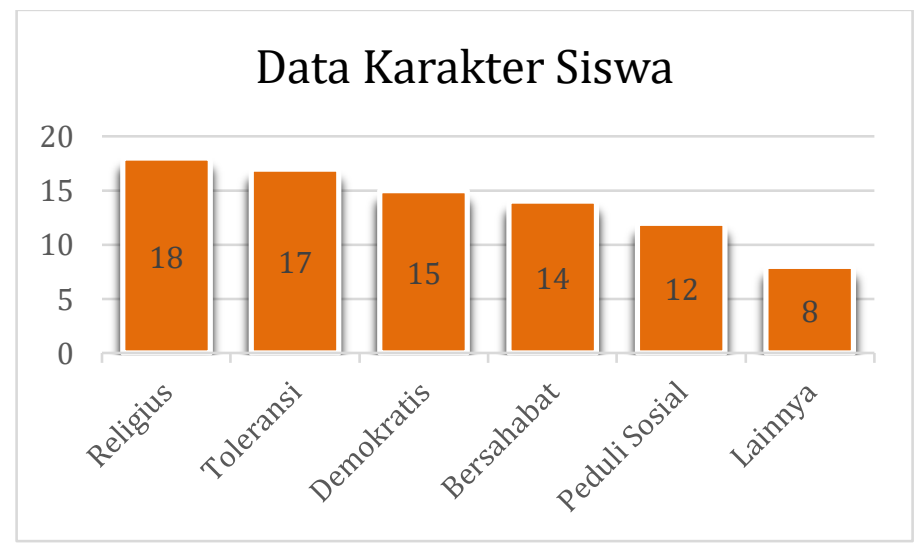

Gambar 2. Data Karakter Siswa

Dari data diagram di atas terlihat bahwa karakter religius merupakan karakter yang banyak dimiliki oleh siswa yaitu 18 anak atau seluruh siswa yang menjadi subjek penelitian. Untuk urutan 
kedua adalah karakter teloransi yang dimiliki oleh 17 siswa, artinya hanya satu siswa yang kurang memiliki karakter toleransi. Selanjutnya karakter demokratis dimiliki oleh 15 orang siswa dan karakter bersahabat dimiliki oleh 14 siswa, selanjutnya peduli sosial merupakan salah satu karakter yang banyak dimiliki oleh siswa SD Negeri 1 Serang yaitu sebanyak 12 siswa. Selain lima karakter tersebut, ada banyak karakter lainnya yang dimiliki siswa namun tidak banyak, hanya 8 anak dari total 18 siswa.

Karakter religius pada siswa SD Negeri 1 Serang tampak pada kegiatan berdoa bersama sebelum dan sesudah belajar, serta turut serta melakukan sholat jamaah dzuhur. Kedua karakter jujur tercermin dari bagaimana siswa tidak menyontek saat sedang melaksanaka ulangan harian, siswa menjawab soal dengan kemampuan sendiri dan tidak melakukan kecurangan. Karakter toleransi juga tampak dari siswa yang saling menghormati teman-temannya yang berbeda agama. Sebagai informasi, di SD Negeri Serang terdapat lebih dari satu kepercayaan yang diimani oleh siswanya yaitu agama Islam dan agama Kristen, meskipun demikian, siswa mampu berdampingan dengan baik tanpa saling menyakiti. Karakter disiplin tampak pada hampir seluruh siswa masuk ke kelas tepat waktu bahkan sebelum bel berbunyi, tidak terlambat mengikuti proses pembelajaran. Karakter berikutnya yaitu kerja keras, hal itu tampak dari bagaimana siswa siswa berusaha mengerjakan tugas yang diberikan oleh guru dengan seluruh kemampuannya, entah tugas individu maupun tugas kelompok.

Karakter keenam yaitu kreatif, hal tersebut tercermin saat siswa mendapatkan tugas membuat karya seni. Setiap siswa akan membuat atau menampilan seni sesuai dengan kreativitas masingmasing. Kemudian karakter mandiri, tampak dari siswa yang datang ke sekolah sendiri atau bersama teman-temannya tanpa harus di antar atau ditunggu di sekolah. Karakter demokratis terlihat saat pemilihan ketua kelas, meskipun pilihan para siswa berbeda akhirnya semua siswa mau menerima keputusan suara terbanyak dalam penentuan ketua kelas. Karakter selanjutnya yaitu rasa ingin tahu, hal tersebut tampak saat siswa berlomba lomba mengangkat tangan ketika guru mempersilahkan untuk bertanya mengenai materi. Selain itu, karakter tersebut juga tampak saat guru memperkenalkan hal baru pada siswa, kemudian siswa bertanya mengenai hal tersebut. Karakter semangat kebangsaan terinternalisasi dengan kegiatan upacara setiap hari senin yang diselenggarakan oleh sekolah.

Tidak jauh berbeda, guru dan siswa mengatakan bahwa karakter cinta tanah air tercermin dari kegiatan upacara yang diikuti oleh siswa. Karakter menghargai prestasi tampak pada siswa yang belajar keras untuk mendapatkan nilai terbaik, guru di SD N 1 Serang mengatakan bahwa ketika siswa berusaha untuk mendapatkan prestasi artinya siswa tersebut menghargai prestasi. Karakter selanjutnya yaitu bersahabat/komunikatif, hal tersebut tampak pada siswa yang mau bergaul dengan siapa saja tanpa membeda bedakan teman. Karakter keempat belas yaitu cinta damai, tampak dari 
siswa yang aku dan tidak suka bertengakar dengan sesama. Karakter selanjutnya yaitu gemar membaca, karakter ini merupakan karakter yang paling sedikit dimiliki oleh siswa, hanya ada sedikit siswa yang langsung bisa menjawab pertanyaan guru tanpa diberi materi terlebih dahulu, siswa yang mampu menjawab karena memiliki karakter gemar membaca, sehingga sebelum melaksanakan proses pembelajaran, sudah membaca materi terlebih dahulu.

Karakter peduli lingkungan tampak pada siswa yang secara sadar memungut sampah yang tidak berada ditempatnya tanpa disuruh. Sedangkan karakter peduli sosial, tercermin dari siswa yang menjenguk temannya yang sakit dan melakukan iuran untuk membantu temannya yang kesusahan. Karakter terakhir dalam kurikulum 2013 yaitu tanggung jawab yang tercermin dari bagaimana siswa SD N 1 Serang mengerjakan tugasnya baik tugas akademik maupun non akademik dengan bersungguh-sungguh.

\section{Latar Belakang Kultural Siswa di Lereng Gunung Slamet}

Latar belakang kultural siswa SD Negeri 1 Serang yang berada di lereng Gunung Slamet meliputi bahasa, sistem mata pencaharian, sistem religi, dan kesenian atau tradisi. Dari segi bahasa, sebagian besar siswa SD Negeri 1 Serang menggunakan bahasa Jawa sebagai alat komunikasi sehari hari, lebih tepatnya bahasa ngapak, sedangkan selama proses pembelajaran menggunakan bahasa Indonesia. Kemudian hasil wawancara menunjukkan bahwa mata pencaharian orang tua siswa dan masyarakat pada umunya di Desa Serang sebagai buruh tani, pedagang, petani, kuli bangunan, montir, karyawan swasta, dan lainnya. Meskipun cukup bervariasi, namun sebagian besar adalah bertani sayuran, mengingan Desa Serang merupakan daerah berhawa dingin.

Kemudian sistem religi di Desa Serang terlihat dari adanya dua kepercayaan yang dianut yaitu agama Islam dan Kristen. Meskipun berbeda keyakinan, kedua umat beragama tersebut hidup berdampingan dengan baik. Desa Serang yang terletak di lereng Gunung Slamet terbilang kaya akan kesenian, di antaranya kuda lumping, tek-tek, rebana, karawitan, dan beberapa lainnya yang sudah mulai hilang. Kesenian tersebut sering ditampilkan pada acara perayaan hari besar agama dan nasional, penyambutan tamu, serta dalam acara tradisi sedekah gunung.

Tradisi sedekah gunung secara khusus menjadi tradisi unik yang hanya dilaksanakan oleh masyarakat di lereng gunung salah satunya Gunung Slamet. Tradisi sedekah gunung dilaksanakan setahun sekali pada bulan Suro. Prosesi sedekah gunung diawali dengan ritual pengambilan air di Teluk Sikopyah yang kemudian air tersebut disemayamkan satu malam kemudian dibagikan kepada sesepuh di beberapa desa di lereng Gunung Slamet. Kemudian ada arak-arakan hasil bumi berupa sayuran dan buah-buahan dengan diiringi beberapa kesenian khas Desa Serang. Ritual terakhir pada tradisi sedekah gunung yaitu memperebutkan hasil bumi berupa buah dan sayuran yang telah diarak. 
Masyarakat percaya jika mendapatkan banyak hasil bumi yang diarak maka akan mendapatkan berkah dan mendapat rezeki yang melimpah. Bagi masyarakat, tradisi sedekah gunung dipercaya dapat menghindari mara bahaya yang dapat ditimbulkan dari Gunung Slamet dan masyarakat Desa Serang dapat hidup dan mendapat penghidupan dengan aman dan nyaman serta dapat memperoleh hasil bumi yang melimpah. Hal tersebut sejalan dengan penelitian yang dilakukan bahwa "Ritual Sedekah Gunung is a tradition that is owned by the Lencoh Village community, Selo, Boyolali. This ritual is part of an agrarian culture. This ritual aims to express gratitude and reject reinforcements (tolak bala). The Lencoh villagers believe that this ritual can save them from danger. The ritual becomes a warning to always maintain the harmony of nature" (Rachmawati dkk, 2018). Berbeda dengan itu, penelitian lain lebih memandang bahwa ritual yang dilaksanakan sebagai bentuk syukur dan mengartikan presensi gunung Merapi yang berada di dekat mereka sebagai berkah yang mengiringi kehidupannya (Prasojo, 2015).

Pada dasarnya tidak berbeda hasil penelitian tersebut dengan tradisi sedekah gunung di lereng Gunung Slamet untuk menyukuri nikmat karena diberi keberkahan. Hal tersebut terbukti dengan melimpahnya hasil bumi seperti panen sayur, dan hasil bumi lainnya yang menjadi sumber kehidupan masyarakat di daerah tersebut. Selain itu tradisi tersebut juga menjadi bentuk syukur atas kerukunan antar warga serta pariwisata yang kian menanjak di lereng Gunung Slamet. Tradisi sedekah gunung secara langsung menarik minat para wisatawan karena kondisi sosial budaya yang unik di lereng Gunung Slamet. Hal tersebut juga terjadi di kawasan gunung Merapi, dengan keunikan dan bencana yang pernah terjadi menjadikan minat wisatawan meningkat (Putri dan Damayanti, 2017).

Tradisi atau kebudayaan yang sudah ada harus dilestarikan agar tidak punah. Melestarikan budaya berarti berusaha menangkal dampak negatif budaya luar yang masuk tanpa filter dan mempengaruhi karakter yang tercermin dari perilaku siswa. Dampak negatif yang berasal dari luar dan dapat mempengaruhi karakter siswa diantaranya gaya hidup berlebihan, konsumtif berlebihan, boros, lunturnya moral, matinya keadilan, individualis dan hilangnya solidaritas yang tidak bagus untuk pendidikan di Indonesia (Kosim, 2019). Berikut tabel latar belakang kultural siswa di SD Negeri 1 Serang.

Tabel 1. Latar Belakang Kultural Siswa di SD N 1 Serang

\begin{tabular}{cll}
\hline No & \multicolumn{1}{c}{ Unsur Budaya } & \multicolumn{1}{c}{ Keterangan } \\
\hline 1 & Bahasa & Bahasa Jawa dan Bahasa Indonesia \\
\hline 2 & Sistem Mata Pencaharian & Buruh tani, pedagang, petani, kuli bangunan, \\
& & montir, karyawan swasta dan lainnya \\
\hline 3 & Sistem Religi & Islam dan Kristen \\
\hline
\end{tabular}




\begin{tabular}{cll}
\hline 4 Kesenian atau Tradisi & Kesenian kuda lumping, tek-tek, rebana, \\
& karawitan dan Tradisi Sedekah Gunung \\
\hline
\end{tabular}

Tabel tersebut menunjukkan keberagaman sistem budaya di SD Negeri 1 Serang. Seperti yang sudah dijelaskan sebelumnya, keberagaman budaya baik dari segi bahasa, sistem mata pencaharian, sistem religi maupun kesenian atau tradisi tidak terlepas dari karakter religius, toleransi, demokratis, bersahabat, dan peduli sosial. Dalam artian bahwa sistem kebudayaan telah membentuk karakter yang ada pada diri siswa.

\section{Pembentukan Karakter Siswa SD Ditinjau dari Latar Belakang Kultural di Lereng Gunung Slamet}

Pembentukan karakter merupakan tujuan utama dari kurikulum 2013. Banyak hal dapat mendukung dan mempengaruhi karakter siswa di SD Negeri 1 Serang, salah satunya adalah latar belakang kultural di lereng Gunung Slamet. Letak SD Negeri 1 Serang yang berada di lereng Gunung Slamet dan memiliki budaya yang sudah mapan dianut oleh masyarakatnya dapat mempengaruhi, bahkan mendukung pembentukan karakter siswa.

Ditinjau dari latar belakang kultural di lereng Gunung Slamet yang dapat membentuk karakter siswa SD Negeri 1 Serang diantaranya bahasa, sistem mata pencaharian, sistem religi, kesenian dan tradisi sedekah gunung. Pada aspek bahasa, hal itu membentuk karakter siswa berupa karakter bersahabat/komunikatif, dengan bahasa Jawa yang digunakan sehari hari siswa mudah bersahabat dan berkomunaksi dengan teman sebaya, selain itu pemilihan bahasa Indonesia saat proses pembelajaran menandakan bahwa siswa mampu menggunakan alat komunikasi sesuai tempatnya. Hal tersebut didikung oleh pernyataan dari siswa A yang mengatakan bahwa "saya selalu menggunakan Bahasa jawa kalau ngomong sama teman, karena sudah biasa, kalau pake Bahasa Indonesia nanti malu" dari pernyataan tersebut juga tercermin dari hasil observasi. Saat istirahat berlangsung, semua siswa bermain di lapangan maupun kelas, semua berkomunikasi menggunakan Bahasa Jawa. Siswa hanya menggunakan Bahasa Indonesia ketika mengikuti proses pembelajaran. Hal tersebut menunjukkan bahwa latar belakang Bahasa membentuk karakter bersahabat/komunikatif.

Aspek kultural kedua yang mempengaruhi pembentukan karakter adalah sistem mata pencaharian. Mata pencaharian masyarakat di Desa Serang yang merupakan orang tua siswa membentuk karakter disiplin, kerja keras, peduli lingkungan dan tanggung jawab. Mata pencaharian orang tua siswa yang sebagian besar sebagai petani buah dan sayur seringkali melibatkan siswa atau anaknya untuk ikut membantu di sawah. Hal tersebut membentuk jiwa disiplin siswa yang harus datang ke sawah sesuai waktunya seperti halnya datang ke sekolah, kerja keras dalam mengerjakan 
tugasnya, peduli lingkungan karena butuh lingkungan yang bersih dan subur untuk dapat ditanami sayur dan buah, hal tersebut membuat siswa terbiasa hidup bersih dan diaplikasikan di sekolah dengan membuang sampah pada tempatnya dalam menjaga lingkungan dan kelestarian alam. Sejalan dengan pernyataan bahwa nilai budaya di daerah pegunungan memotivasi masyaraktanya untuk bertani dengan menjaga kelestarian alam dan semangat bekerja (Mulaydi dan Iyai, 2016). Kemudian tanggung jawab dalam melaksanakan tugasnya baik membantu orang tua di sawah atau tugas yang diberikan guru di sekolah.

Aspek ketiga yaitu sistem religi pada siswa dan masyarakat di desa Serang. Aspek ini turut serta membentuk banyak karakter diantaranya religius, jujur, toleransi, cinta damai, dan peduli sosial. Agama yang dianut siswa membentuk karakter religius, dengan berdoa sebelum dan setelah belajar sesuai agama masing-masing. Setiap agama juga mengajarkan untuk bersikap jujur karena jika tidak jujur akan mendapat doa, sehingga siswa hal tersebut membentuk karakter jujur yang diaplikasikan saat mengerjakan soal ujian. Kemudian sistem religi di Desa Serang juga membentuk karakter toleransi dan cinta damai, hal tersebut berkaitan dengan agama yang dianut oleh warga sekolah SD N 1 Serang dan masyarakat Desa Serang yang menganut dua agama yaitu Islam dan Kristen sehingga terbiasa hidup berdampingan dengan damai dan saling menghormati. Kemudian karakter peduli sosial juga dibentuk oleh sistem religi, karena gama juga mengajarkan untuk saling tolong menolong terhadap sesama.

Aspek terakhir dari unsur budaya/kultur yang membentuk karakter siswa yaitu kesenian dan tradisi. Kesenian kuda lumping, tek-tek, dan rebana membentuk karakter kreatif, semangat kebangsaan, cinta tanah air, dan bersahabat/komunikatif. Seni berhubungan dengan kreativitas, anak yang turut serta dalam kesenian akan terbentuk karakter kreatif. Kemudian ketiga kesenian tersebut juga merupakan aset bangsa artinya kegiatan berkesenian tersebut akan membentuk karakter semangat kebangsaan dan cinta tanah air. Selain dari beberapa hal tersebut, di sisi lain kesenian yang dilakukan oleh siswa di SD Negeri 1 Serang juga bisa menumbuhkan karakter mandiri dan bertanggung jawab. Hal tersebut karena siswa yang mengikuti grup kesenian tek tek seringkali mengadakan latihan sekaligus mencari uang dengan mengamen di pinggir jalan. Selain itu ketiga kesenian tersebut dilakukan secara berkelompok sehingga dapat membentuk karakter bersahabat/komunikatif. Selain ketiga kesenian tersebut, terdapat suatu tradisi yang diberi nama sedekah gunung.

Tradisi sedekah gunung yang rutin dilaksanakan oleh masyarakat di lereng Gunung Slamet, tepatnya Desa Serang membentuk berbagai karakter siswa diantaranya religius, toleransi, cinta tanah air, semangat kebangsaan, peduli lingkungan, cinta damai, dan peduli sosial. Karakter religi terbentuk 
melalui prosesi pengambilan air suci dari teluk Sikopyah yang kemudian disemayamkan dan dibagikan kepada para sesepuh hingga mengarak hasil bumi merupakan kepercayaan diyakini oleh masyarakat di lereng Gunung Slamet. Sejalan dengan pernyataan dari salah seorang warga setempat yang menjelaskan bahwa "tradisi ini sudah turun menurun jadi harus diawali pengambilan air suci oleh sesepuh yang dihormati”. Kemudian prosesi selanjutnya yaitu memperebutkan hasil bumi yang telah diarak membentuk karakter cinta damai dimana meskipun berebut tapi tetap dalam suasana damai dan membahagiakan. Salah seroang masyarakat menyatakan bahwa "memang harus rebutan, tapi ya tidak rebut, kita percaya rejekinya sudah diatur sama Allah”. Proses berebut sedekah gunung yang tetap damai tanpa perkelahian tersebut membentuk karakter cinta damai yang diaplikasikan dengan tetap berteman meskipun bersaing dalam memperoleh ranking di kelas. Kemudian karakter peduli sosial dibentuk dari prosesi memperebutkan hasil bumi, semua orang boleh membawa hasil bumi yang telah diarak bahkan beberpa orang memberikan hasil bumi yang ia dapatkan ke orang lain yang membutuhkan. Kemudian secara umum tradisi sedekah gunung membentuk karakter semangat kebangsaan dan cinta tanah air, karena dengan tetap melaksanakan tradisi ini artinya masyarakat mempertahankan budaya yang menjadi kekayaan bangsa.

Tradisi sedekah gunung ini memiliki dampak yang hampir sama dengan tradisi upacara Kasada yaitu membentuk integrasi sosial serta solidaritas melalui pelaksanaan upacara yang akan memperkuat eksistensi sebagai masyarakat komunal, sedangkan secara ekologis upacara tersebut akan menyadarkan masyarakat tentang keadaan lingkungan alam pegunungan yang terbatas dan harus dijaga (Hadi, 2014). Sebagian besar tradisi yang melekat dan ada di masyarakat bertujuan untuk menjaga alam dan kelangsungan kehidupan masyarakat, alam dan manusia dirasa harus saling menjaga satu sama lain.

Tebel.2 Pembentukan Karakter

\begin{tabular}{cll}
\hline No & \multicolumn{2}{c}{ Unsur Budaya } \\
\hline 1 & Bahasa & bersahabat/komunikatif \\
\hline 2 & Sistem Mata Pencaharian & $\begin{array}{l}\text { disiplin, kerja keras, peduli lingkungan dan } \\
\text { tanggung jawab. }\end{array}$ \\
\hline 3 & Sistem Religi & religius, jujur, toleransi, cinta damai, dan peduli \\
& & sosial \\
\hline 4 & Kesenian atau Tradisi & $\begin{array}{l}\text { kreatif, semangat kebangsaan, cinta tanah air dan } \\
\text { bersahabat/komunikatif }\end{array}$ \\
\hline
\end{tabular}

Dalam penjelasan ini, terlihat jelas sistem budaya bahasa dari siswa dapat membentuk karakter bersahabat dan komunikatif, hal tersebut dialami oleh semua subjek penelitian. Kemudian sistem mata pencaharian di Desa Serang membentuk karakter disiplin, kerja keras, peduli lingkungan dan 
tanggung jawab. Hal tersebut dirangkum dari beberapa jawaban siswa, karena latar belakang mata pencarahiran orang tua masing-masing siswa berbeda. Bagi siswa yang memiliki latar belakang keluarga dengan mata pencaharian bertani maka karakter yang melekat adalah disiplin karena harus sering datang ke ladang setiap pagi. Karakter kerja keras dan tanggung jawab terbentuk pada siswa dari latar belakang mata pencaharian dari profesi atau pekerjaan apapun.

Kemudian untuk peduli lingkungan, terbentuk dari sistem mata pencaharian bertani. Sebagai anak dari orang tua yang memenuhi kebutuhan dengan mengandalkan alam, anak menjadi terbentuk rasa hormat kepada alam dan lingkungan, sehingga membentuk karakter peduli lingkungan. Selain itu, karakters peduli lingkungan juga terbentuk dari sistem religi, dimana setiap agama mengajarakan umatnya untuk peduli terhadap lingkungan. Tradisi sedekah gunung yang dilaksanakan masyarakat Desa Serang juga membentuk karakter peduli lingkungan. Kegiatan yang dilaksanakan pada tradisi sedekah gunung menggambarkan karakter peduli lingkungan sehingga membentuk karakter peduli lingkungan pada siswa di SD N 1 Serang.

Sistem religi pada budaya di Desa Serang membentuk karakter religius, jujur, toleransi, cinta damai, dan peduli sosial. Karakter religius sangat melekat pada siswa karena memiliki kepercayaan atau agama yang dianut, lingkungan yang mendukung kegiatan keagamaan juga membentuk siswa memiliki karakter religius. Karakter toleransi dan cinta damai terbentuk karena terdapat keberagaman agama yang ada di desa Serang. Kemudian untuk karakter jujur dan peduli sosial terbentuk dari ajaran agama dan kepercayaan yang dianut siswa, karena semua agama mengajarkan sikap jujur dan peduli terhadap sesama.

Kesenian dan tradisi yang berkembang di Desa Serang membentuk karakter kreatif, semangat kebangsaan, cinta tanah air dan bersahabat/komunikatif. Semua karakter tersebut dibentuk dengan budaya yang ada di Desa Serang dan melekat serta dilestarikan oleh masyarakat Desa Serang secara umum dan siswa di SD Negeri 1 Serang secara khusus.

\section{PENUTUP}

Dari pemaparan yang telah dijelaskan sebelumnya pada hasil dan pembahasan, dapat disimpulkan bahwa latar belakang kultural di lereng Gunung Slamet membentuk karakter siswa SD 1 Serang. Hal tersebut tampak pada unsur bahasa yang membentuk karakter karakter bersahabat/komunikatif, kemudian unsur mata pencaharian membentuk karakter disiplin, kerja keras, peduli lingkungan dan tanggung jawab. Selain itu unsur religi mmbentuk berbagai karakter yaitu religius, jujur, cinta damai, toleransi, dan peduli sosial. Unsur terakhir yaitu kesenian dan tradisi dimana kesenian membentuk karakter kreatif, cinta tanah air, bersahabat/komunikatif dan semangat 
kebangsaan, sedangkan tradisi membentuk karakter religius, toleransi, cinta tanah air, semangat kebangsaan, cinta damai, peduli sosial, dan peduli lingkungan. Pembentukan karakter tersebut tidak terlepas dari peran orang tua, guru, semua pihak sekolah dan masyarakat sekitar di Desa Serang.

\section{DAFTAR PUSTAKA}

Aqib, Z. (2012). Pendidikan Karakter di Sekolah. Bandung: Yarma Widya

Barnawi \& Arifin. (2012). Strategi \& Kebijakan Pembelajaran Pendidikan Karakter. Jogjakarta: Ar-ruzz Media

Hadi, Nur. (2014). Pengembangan Bahan Bacaan Berbasis Pendidikan Multi Kultural, Religi Komunitas Pegunungan: Studi Kasus Pada Masyarakat Terunyan di Gunung Batur, Tengger di Gunung Bromo dan Kinahrejo di Lereng Merapi. Sejarah dan Budaya, Tahun Kedelapan, Nomor 1, 25-40

Kaimuddin. (2014). Implementasi Pendidikan Karakter Dalam Kurikulum 2013. Dinamika Ilmu, $14(1), 47-64$

Kementrian Pendidikan Nasional. (2010). Buku Induk Pembangunan Karakter. Jakarta: Kementrian Pendidikan Nasional Badan Penelitian dan Pengembangan Pusat Kurikulum dan Perbukuan.

Koentjaraningrat. (2015). Pengantar Ilmu Antropologi. Jakarta: Rineka Cipta.

Kosim, Abdul. (2019). Internalisasi Pendidikan Karakter Berbasis School Culture. Jurnal Wahana Karya Ilmiah_Pascasarjana (S2) PAI Unsika, 3 (1), 240-251

Mulyadi dan Deny A. Iyai. (2016). Pengaruh Nilai Budaya Lokal terhadap Motivasi Bertani Suku Arfak di Papua Barat. Jurnal Peternakan Sriwijaya, 1. 5(1), 18 - 29

Piazza, S. V., Rao, S., \& Protacio, M. S. (2015). Converging Recommendations for Culturally Responsive Literacy Practices: Students with Learning Disabilities, English Language Learners, and Socioculturally Diverse Learners. International Journal of Multicultural Education, 17(3). Western Michigan University

Pranata, M. (2013). Pendidikan Karakter. Malang: Bayu Media Publising.

Prasojo, M. Nur Budi. (2015). Konstruksi Sosial Masyarakat Terhadap Alam Gunung Merapi: Studi Kualitatif tentang Kearifan Lokal yang Berkembang di Desa Tlogolele Kecamatan Selo Kabupaten Boyolali. Jurnal Analisa Sosiologi, 4(2), $31-46$ 
Putri, Shafira Leliana Putri dan Maya Damayanti. (2017). Peran SumberDaya Sosial Budaya dalam Pengembangan Pariwisata di Kawasan Gunung Merapi Desa Umbulharjo dan Desa Kepuharjo. RUANG, 3(1), 1-10

Putry, Raihan. (2018). Nilai Pendidikan Karakter Anak di Sekolah Perspektif Kemendiknas.

Internasional. Journal of Child and Gender Studies, 4 (1), 39-54

Rachmawati, Julianne Indah., Warto dan Titis Srimuda Pitana. (2018). Selling Sacredness:

Representation of Sedekah Gunung Ritual in Lencoh Village, Boyolali in New Media. Mozaik Humaniora, 18 (2), 178-188

Rahayu, Dewi Widiana. (2016). Internalisasi Nilai Karakter Melalui Budaya Sekolah. Jurnal Buana Pendidikan. Tahun XII, No. 22, 49-68

Salahudin, A. (2013). Pendidikan Karakter Berbasis Pendidikan Agama dan Budaya Bangsa. Bandung: Pustaka Setia.

Soekanto, Soerjono. (2017). Sosiologi Suatu Pengantar. Jakarta: Rajawali Press

Sudarmiani. (2013). Membangun Karakter Anak Dengan Budaya Kearifan Lokal Dalam Proses Pembelajaran di Sekolah. Jurnal Equiliribium, 1 (1), 54-72

Sugiyono. (2018). Metode Penelitian Kualitatif (Untuk penelitian yang bersifat: eksploratif, enterpretatif, interaktif dan konstruktif. Bandung: Alfabeta.

Syafei, Nur. (2019). Murid SD di Surabaya Melawan Guru karena Ditegur Merokok. Sindonews.com. https://daerah.sindonews.com/berita/1398934/174/murid-sd-di-surabaya-melawan-gurukarena-ditegur-merokok.

Wibowo, A. (2013). Manajemen Pendidikan Karakter di Sekolah. Yogyakarta: Pustaka Pelajar 
PEMBANGUNAN KARAKTER SISWA SD DITINJAU DARI LATAR BELAKANG KEBUDAYAAN ...

Itsna Oktaviyani, Kiki Indah Pratiwi 